\title{
Palaeostress and kinematic evolution of the orogen-parallel NW-SE striking faults in the NW External Dinarides of Slovenia unraveled by mesoscale fault-slip data analysis
}

\author{
Lea Žibret ${ }^{1,2}$ and Marko Vrabec ${ }^{1}$ \\ 1 University of Ljubljana, Faculty of Natural Sciences and Engineering, Department of Geology, Privoz 11, SI-1000 Ljubljana, Slovenia \\ ${ }^{2}$ Research and development in the field of natural sciences, Černetova ulica 3A, SI-1000 Ljubljana, Slovenia; (corresponding author: zibret.lea@gmail.com) \\ doi: $10.4154 / g c .2016 .30$ \\ Crossref

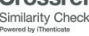

Article history:

Manuscript received February 27, 2016

Revised manuscript accepted September 16, 2016 Available online October 07, 2016

\begin{abstract}
The late Eocene to Recent dynamics of the NW External Dinarides in Slovenia are described. The study is focused on the orogen-parallel NW-SE striking family of faults, which represent the main source of seismic hazard in the NW External Dinarides today. Approximately 1700 faultslip datasets were collected at 70 locations and used for palaeostress analysis. Structural relationships observed in the field, allowed the construction of a relative chronology between the documented fault and shear joint sets, facilitating the reconstruction of their kinematic evolution and the chronology of palaeostress phases. Four post-Palaeocene stress tensor groups are documented corresponding to four distinct tectonic phases. The first phase is marked by NE-SW directed compression attributed to Late Eocene top-to-SW thrusting of External Dinarides. The second phase is characterized by NE-SW oriented tension, documented by normal slips recorded on NW-SE striking faults. This tension is interpreted as an expression of the Early to Middle Miocene back-arc extension in the Pannonian basin system that also affected the studied part of the External Dinarides. The third phase is manifested by approximately E-W oriented compression with approximately $\mathrm{N}$-S oriented tension in a strike-slip stress regime, causing sinistral reactivation of NW-SE trending faults. Geodynamically, this phase can be correlated with the Late Miocene short pulse of E-W directed compression, documented in parts of the Pannonian basin system. The youngest phase is characterized by approximately $\mathrm{N}$-S oriented compression and approximately E-W oriented tension in a strike-slip stress regime, which caused dextral reactivation of NW-SE striking faults. This phase correlates with the recent inversive/transpressive phase, well-established from seismological data.
\end{abstract}

Keywords: fault-slip analysis, palaeostress Dinarides ximately $190 \mathrm{~km}$ total N-S shortening (USTASZEWSKI et al., 2008). In the kinematic reconstruction of PLACER $(1981,1998)$ the total SW-NE directed shortening across the Slovenian External Dinarides is around $50 \mathrm{~km}$.

In the NW External Dinarides the major structures which accommodate recent crustal stresses are steep to subvertical NW-SE striking faults with a significant linear topographic expression, evident on a regional scale. They cut and displace Dinaric and South-Alpine thrust-related structures and are therefore commonly interpreted as reflecting the final stage of the tectonic evolution of the Dinarides (PICHA, 2002; VRABEC \& FODOR, 2006). Their neotectonic importance is supported by earthquake focal mechanisms, which predominantly illustrate a strike-slip stress regime with a NNW-SSE directed $\sigma_{1}$ axis (POLJAK et al., 2000; KASTELIC et al., 2008; HERAK et al., 2009; KASTELIC et al., 2013). Recent NNW-SSE oriented contraction is also evident from regional GPS data analysis (WEBER et al., 2006; WEBER et al., 2010), analysis of geomorphic markers (JAMŠEK RUPNIK et al., 2014; MOULIN et al., 2014; ŽIBRET \& ŽIBRET, 2014), and geophysical investigations (GOSAR, 1998; BAVEC et al., 2012; ZAJC et al., 2015). Spatial analysis of earthquake events demonstrates complex interactions in the fault zones, likely controlled by their complex geometry originating in their polyphase tectonic evolution (e.g. KASTELIC et al., 2008). To date, only a few studies have investigated late-orogenic structural and geodynamic evolution of the Dinarides, mostly in the Central Inter- nal Dinarides of Croatia, Bosnia and Herzegovina, and Albania
6). According to map-view reconstructions, the north motion of the Adria microplate in the Neogene resulted in appro- 
(PAMIĆ et al., 1998; TOMLJENOVIĆ \& CSONTOS, 2001; PICHA, 2002; TARI, 2002; ILIĆ \& NEUBAUER, 2005, TOMLJENOVIĆ et al., 2008; USTASZEWSKI et al., 2010), while there is no integrated study concerning the Neogene tectonic evolution of the NW External Dinarides of Slovenia. The aim of this study is to reconstruct the palaeostress evolution in the NW External Dinarides and to examine the kinematic history of the NW-SE striking orogen parallel faults.

In the central part of the Dinarides, the oldest Cenozoic tectonic phase is characterized by generally NE-SW to E-W oriented compression, related to Palaeogene thrusting of the Dinarides towards the W-SW onto an undeformed Adria microplate (ILIĆ \& NEUBAUER, 2005). There, the Oligocene to Early Miocene transition was characterized by post collisional volcanism, probably partly controlled by E-W oriented tension, since the magmatic processes during the aforementioned period were much more complex (MLADENOVIĆ et al., 2015). The Early and Middle Miocene is marked by NE-SW oriented tension, perpendicular to the strike of the Dinaric orogen. According to interpretations by TOMLJENOVIĆ \& CSONTOS (2001), ILIĆ \& NEUBAUER (2005) and USTASZEWSKI et al. (2010) the Early and Middle Miocene orogen-perpendicular tensional phase was related to syn-rift extension in the Pannonian basin system. In the central part of the Dinarides of Eastern Bosnia the Middle Miocene tensional phase becomes orogen-parallel (ILIĆ \& NEUBAUER, 2005). Between the Late Miocene and Pliocene, subduction in the Carpathians terminated (HORVÁTH \& CLOETINGH, 1996), causing a regional change in the stress regime. In the Dinarides this episode is reflected by generally N-S oriented compression in the strike-slip tectonic regime (ILIĆ \& NEUBAUER, 2005, MLADENOVIĆ et al., 2015). The ongoing North directed push of the Adria microplate and termination of subduction in the Carpathian arc, which facilitated free movements of continental blocks towards the east during the Late Oligocene - Miocene, induced a counter-clockwise rotation of the Adria microplate during the Pliocene and Quaternary (MÁRTON et al., 2002). Today this is evident in decreased rates of slip along active faults from the SE to the NW External Dinarides (WEBER et al., 2010; KASTELIC \& CARAFA, 2012).

\section{DATA COLLECTION AND PROCESSING}

Approximately 1700 fault-slip measurements acquired at 70 localities in the NW External Dinarides were analysed. Fault-slip data was collected at 51 localities in Mesozoic sediments derived from the Dinaric carbonate platform and in Miocene sediments of the Central Paratethyan area of Slovenia. Measurements were supplemented by data from GREGORIČ (2005) collected at 19 localities in Palaeogene sediments of Dinaric foreland basins (Fig. 1). Analysis included orientation of fault-plane and fault-slip lineation with the sense of slip determined using different types of kinematic indicators (e.g. PETIT, 1987; DOBLAS, 1998; SPERNER \& ZWEIGEL, 2010).

Stress tensors were calculated by inversion of measured fault-slip data. These methods are based on the assumption that the direction of movement and the shear stress along the fault are parallel (WALLACE, 1951; BOTT, 1959). The mean stress tensor was determined, knowing the orientations and senses of slip on numerous faults, assuming that each observed fault-slip (indicated by a slickenside lineation) has the direction and sense of shear stress that corresponds to a single common stress tensor (ANGELIER, 1994). A fault-slip dataset may involve errors caused by dispersion in local stress patterns as well as fault seg-

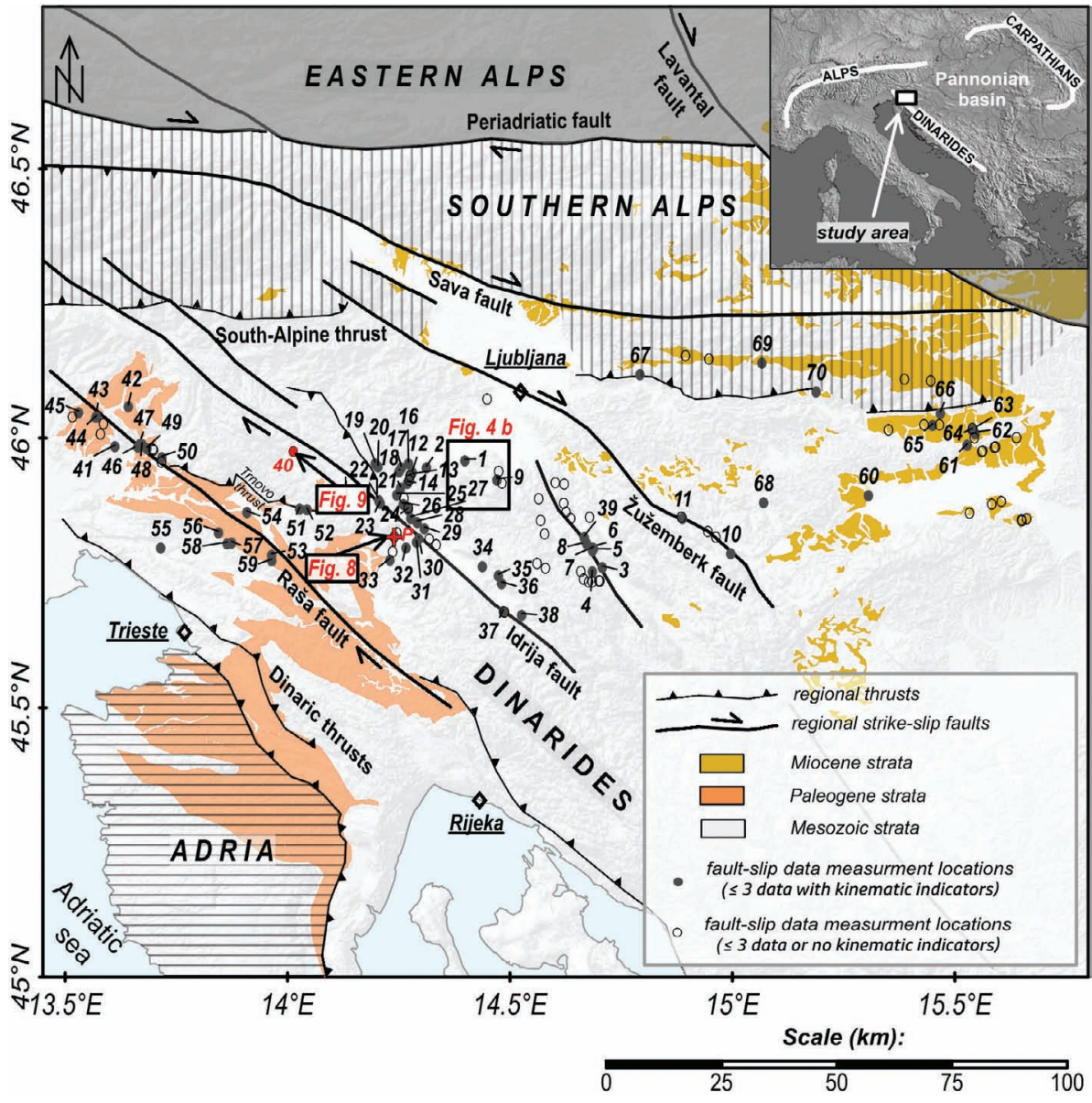

Figure 1. Fault-slip data measurement locations in the NW External Dinarides of Slovenia. Traces of major thrusts and strike-slip faults are compiled from VRABEC \& FODOR (2006), KASTELIC et al. (2008), TOMLJENOVIĆ et al. (2008) and BUSETTI et al. (2010). Stratigraphic units are simplified after BUDKOVIČ et al. (2003). 
ment interplay and for other reasons. Therefore, the aim is to look for the best fit between measured fault-slip data and a theoretical common stress tensor. The misfit between these is described by the angle between the actual slip and the theoretical shear stress on a fault plane (ANGELIER, 1994), the so called „misfit criteria”.

Stress tensors are generally described by six independent variables in matrix form (equation (1); ANGELIER, 1994):

$$
\begin{array}{lll}
a & d & e \\
d & b & f \\
e & f & c
\end{array}
$$

in the co-ordinate system defined by the principal stress axes (equation (2); ANGELIER, 1994):

$$
\begin{array}{ccc}
\sigma 1 & 0 & 0 \\
0 & \sigma 2 & 0 \\
0 & 0 & \sigma 3
\end{array}
$$

Three components of the stress tensor (eigenvalues) describe the orientation of the principal stress axes $\sigma_{1}, \sigma_{2}, \sigma_{3}$, where: $\sigma_{1}$ (maximum stress), $\sigma_{2}$ (intermediate stress) and $\sigma_{3}$ (minimum stress), and where $\sigma_{1} \geq \sigma_{2} \geq \sigma_{3}$. A fourth value is the ratio between the eigenvalues of a stress tensor (Bishop's (1966) stress parameter) which describes the relative magnitude of the eigenvalues: $\phi=\left(\sigma_{2}-\sigma_{3}\right) /\left(\sigma_{1}-\sigma_{3}\right)$. The last two variables describe the frictional and brittle characteristics of a rock mass (ANGELIER, 1994). However, it is not possible to estimate frictional and brittle characteristics directly from fault-slip data. Therefore only reduced stress tensors with four variables (eigenvalues and $\phi$ ) can be determined.

For palaeostress analysis the Gauss method (ŽALOHAR \& VRABEC, 2007) and the Multiple-slip method (ŽALOHAR \& VRABEC, 2008) were used. In the Gauss method, the distribution of the misfit angle between the measured direction of slip and shear stress is approximated with the Gaussian distribution and an optimal stress tensor is determined by maximizing the Gaussian function (ŽALOHAR \& VRABEC, 2007). The Multiple-slip method combines kinematic and dynamic approaches (ŽALOHAR \& VRABEC, 2008). A fault plane is activated only when the applied shear stress exceeds the frictional shear strength. In both methods mechanical compatibility of solutions for individual stress tensors is controlled by the three-dimensional Mohr diagram.

Since most of the study region comprises highly deformed rocks and the orientation of the sedimentary beds changes very rapidly (in some cases every few metres), palaeostress inversion has been undertaken separately for each measurement location (outcrop). Where the orientation of sedimentary beds changes within the individual outcrop, the location was divided into an appropriate number of sub-locations with constant bed orientation, and each sub-location was then analysed separately. Because the measured fault-slip data were highly heterogeneous, each dataset (each locality/sub-locality) has been manually separated into homogeneous data subsets using a maximum misfit criteria of $30^{\circ}$.

In strike-slip fault zones internal block rotations are common (e.g. NOZAEM et al., 2013), and regional block rotations were also inferred in the study area (VRABEC \& FODOR, 2006). Therefore some allowance was made in the analyses for variations in the orientation of principal stress axes, and stress fields close in axis orientation were assumed to have originated in the same general regional stress fields. A detailed description of the data separation procedure and of calculated palaeostress parameters for individual fault subsets is documented in the first author's PhD thesis (ŽIBRET, 2015).

Regional relevance of the determined stress fields is supported by their consistent occurrence throughout the study area. A first-order timing constraint for palaeostress phases is given by the stratigraphic ages of rocks in which the respective fault-slip data occur. However, this only gives a very rough time bracket since the majority of investigated rocks are Mesozoic in age. A relative chronology of documented palaeostress phases was derived from the following field criteria:

- overprinting relationships between different families of fault striations on the same fault plane,

- cross-cutting relationships between outcrop-scale and regional-scale faults, and

- ductile/brittle character of deformation, assuming ductile phases preceded brittle deformations.

\section{REGIONAL PALAEOSTRESS PHASES}

\subsection{Documented palaeostress tensors} NE-SW compression (Phase 1)

The first phase (Phase 1, Fig. 2) is characterized by a NE-SW directed maximum palaeostress axis $\sigma_{1}$, and approximately vertical $\sigma_{3}$ axis. This phase is manifested on reverse NW-SE striking faults and thrusts, which dip from $30^{\circ}$ to $75^{\circ}$ towards the SW and NE. It was reconstructed by fault-slip data recorded at only about $15 \%$ of the measured sites and thus it seems that they are not well preserved, probably because of overprinting by younger movements. Nevertheless, in some places mesoscopic-scale duplex structures indicating NE-SW directed compression have been observed.
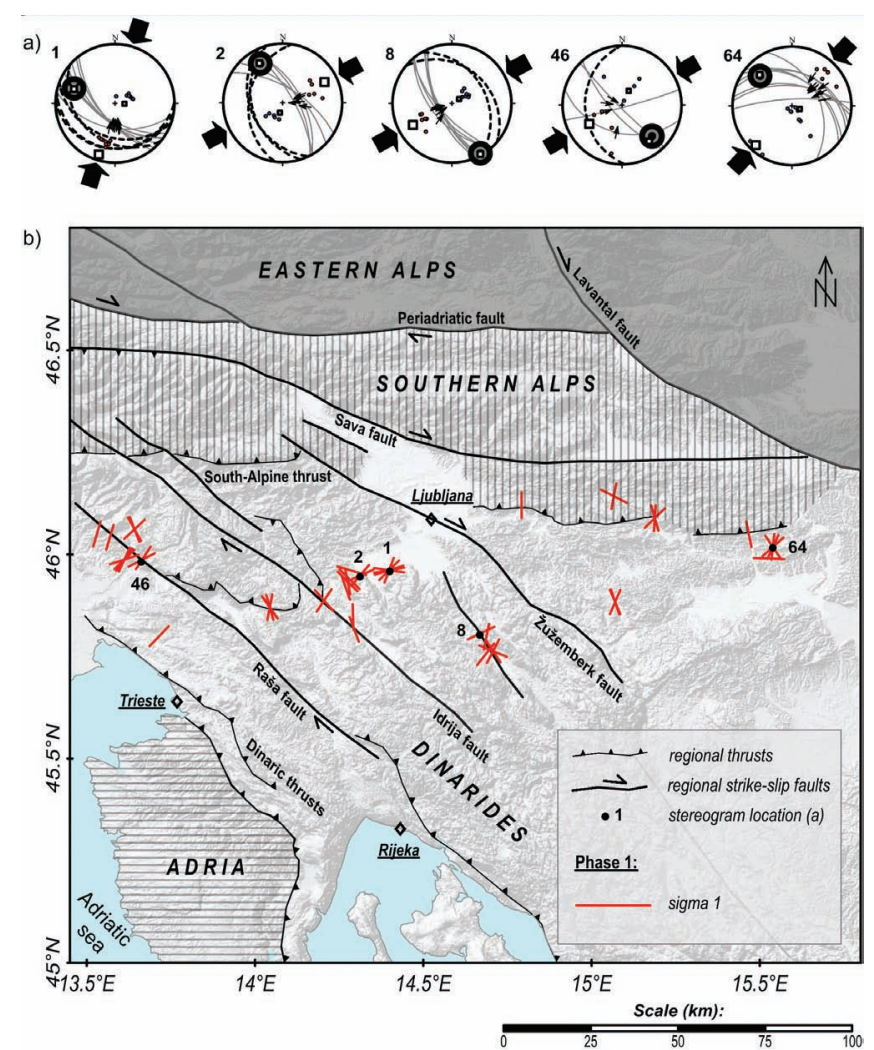

Figure 2. a) Examples of fault-slip data and derived stress tensors for Phase 1. b) Regional stress field of Phase 1 (in present-day reference frame, not accounting for any vertical-axis rotations). 


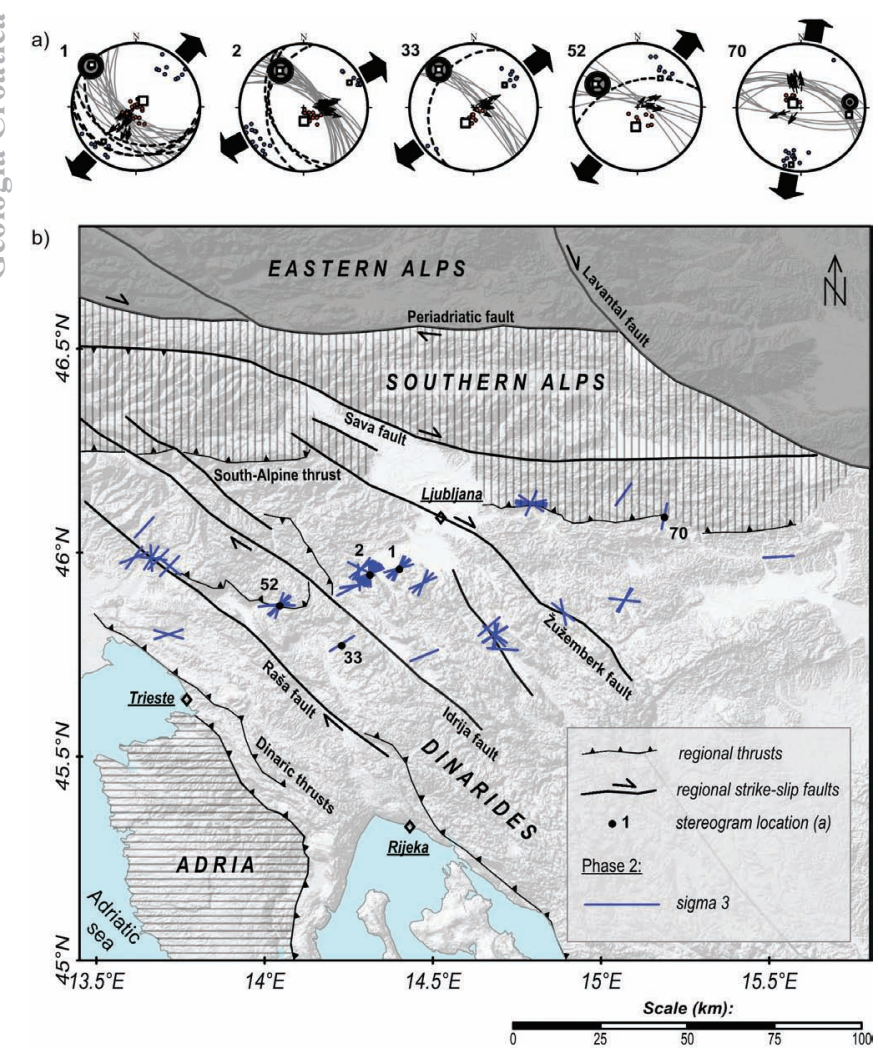

Figure 3. a) Examples of fault-slip data and derived stress tensors for Phase 2. b) Regional stress field of Phase 2 (in present-day reference frame, not accounting for any vertical-axis rotations).

\section{NE-SW tension (Phase 2)}

The second phase (Phase 2, Fig. 3) is marked by a NE-SW oriented minimum palaeostress axis $\sigma_{3}$ and an approximately vertical $\sigma_{1}$ axis. Fault-slip data that document this phase are very ubiquitous. At almost $40 \%$ of the measured locations, normal to oblique-normal slips on steep to moderately dipping fault planes (dipping $60^{\circ}$ to $85^{\circ}$ towards NE or SW) have been recorded indicating a NE-SW directed tensional phase.

Structures originating from this palaeostress phase are noticeably present in both mesoscopic and map scales of observation. NW-SE striking faults with a normal sense of slip, dipping around $60^{\circ}$ towards the NE or SW, often exhibiting conjugate geometry typical for neo-formed normal faults, were observed in many outcrops. At the map scale, normal offsets on NW-SE striking faults have also been recorded in several places. One example is presented in Figure 4., where consistent dipping of beds towards the faults suggests that normal faulting was accompanied by domino-style rotations of their hanging wall blocks.

\section{E-W compression in a strike-slip regime (Phase 3 )}

The third phase (Phase 3, Fig. 5) is characterized by a palaeostress tensor with approximately E-W trending $\sigma_{1}$ and N-S oriented $\sigma_{3}$ axes in the strike-slip stress regime. This phase is typically represented by sinistral reactivations of NW-SE striking fault planes. It was recognized at approximately $20 \%$ of sites and is apparently a rather weak phase, since (except for collected fault-slip data) neither outcrop-scale nor map-scale structures were discovered that could be reliably related to this phase.

\section{$\mathrm{N}-\mathrm{S}$ compression in strike-slip regime (Phase 4)}

The fourth phase (Phase 4, Fig. 6) is characterised by an approximately N-S oriented maximum palaeostress axis $\sigma_{1}$ with approxi-

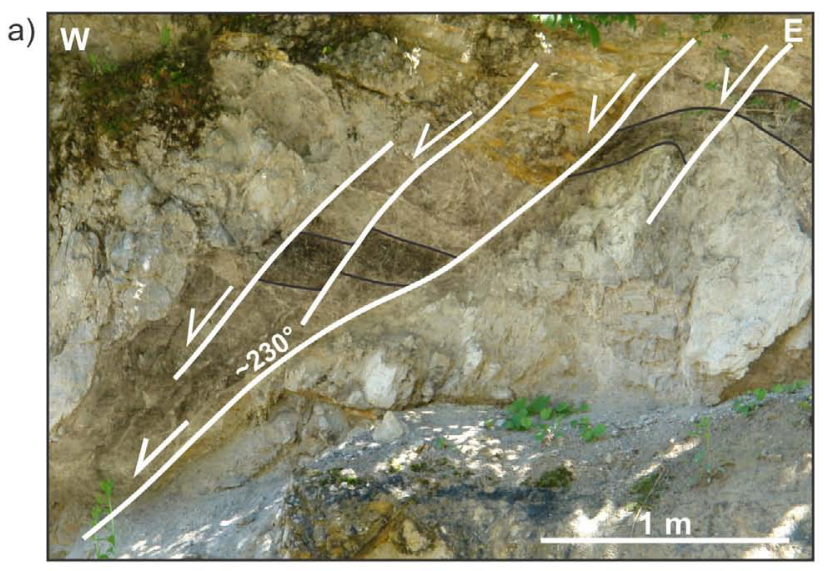

b)
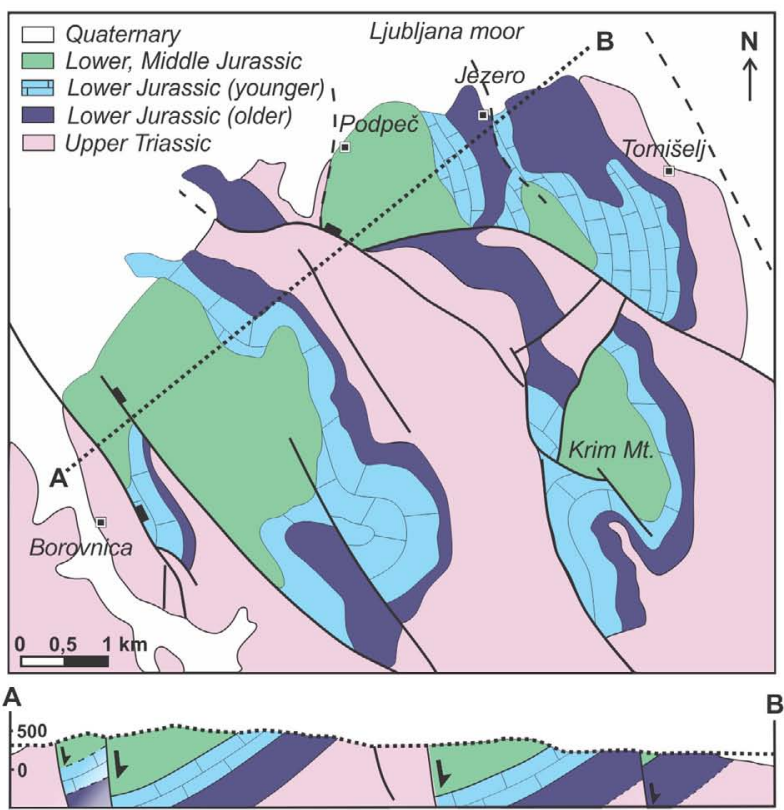

Figure 4. Examples of normal faulting in NE-SW tension (Phase 2). a) Outcropscale normal faults in Triassic dolomite at location $6(x=72804, y=475508)$. b) Map-scale normal faults south of Ljubljana (for location see in Fig. 1), indicating domino-style rotations of hanging wall blocks (adapted from BUSER et al., 1963).

mately E-W trending $\sigma_{3}$ axis in the strike-slip stress regime. Besides, it is presumed to be contemporaneous with NNW-SSE oriented maximum palaeostress axis $\sigma_{1}$ in compressional stress regime. Locally, the trend of $\sigma_{1}$ is NNE-SSW (Fig. 6b) and close to regional strike-slip faults, which could be explained as local vertical-axis block rotations. This stress-strain relationship is very common throughout the study area and was documented at more than $70 \%$ of the analysed locations. The main manifestation of this phase is a dextral reactivation of NW-SE-trending fault planes.

\subsection{Relative chronology of documented palaeostress phases}

The first-order constraint on the time-span of documented palaeostress phases is given by the biostratigraphic age of sedimentary rocks in which the data were acquired. Most of the studied rocks in the NW External Dinarides in Slovenia (Fig. 1) originated from the Mesozoic-Palaeogene Adriatic carbonate platform (TURNŠEK et al., 1982; ČRNE \& GORIČAN, 2008; JEŽ et al., 2011), overlain in the W and SW part by a roughly NW-SE-trending belt of Palaeocene to Eocene Dinaric foreland flysch basin sediments (DEBELJAK et al., 2002; OTONIČAR, 2007; DROBNE et al., 2011; PAVLOVEC, 2012). Besides, in the NE part of the study area, the youngest analysed sediments belong to Central 

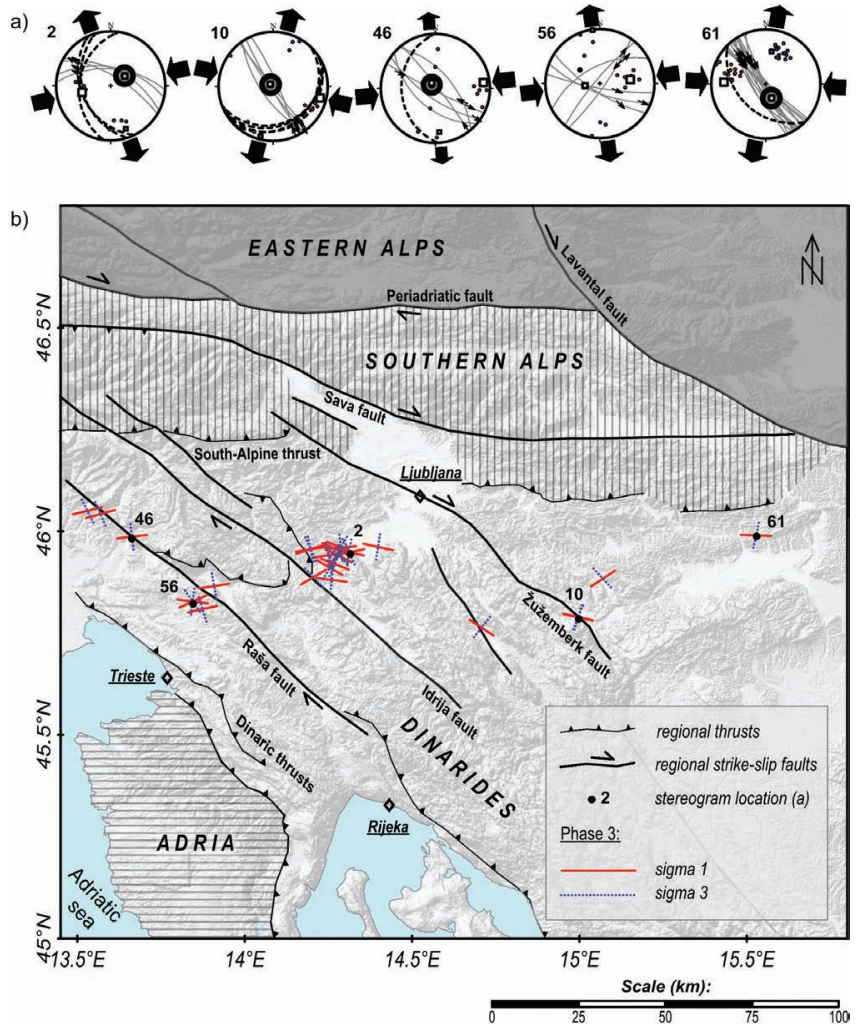

Figure 5. a) Examples of fault-slip data and derived stress tensors for Phase 3. b) Regional stress field of Phase 3 (in present-day reference frame, not accounting for any vertical-axis rotations).

Paratethyan formations dating from the Palaeocene to Late Middle Miocene (FODOR et al., 1998; JELEN \& RIFELJ, 2002; FODOR et al., 2002; MIKUŽ et al., 2012; BARTOL et al., 2014).

As previously described in Section 2, the relative chronology of palaeostress phases (Phase 1-Phase 4) is based on direct field observations of fault-slip data, their cross cutting relationships and the deformation style. Each of the three criteria is described below with representative examples.

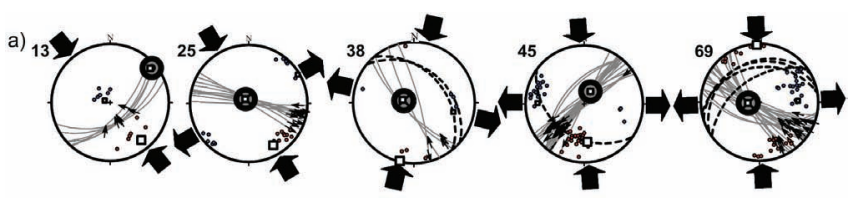

b)

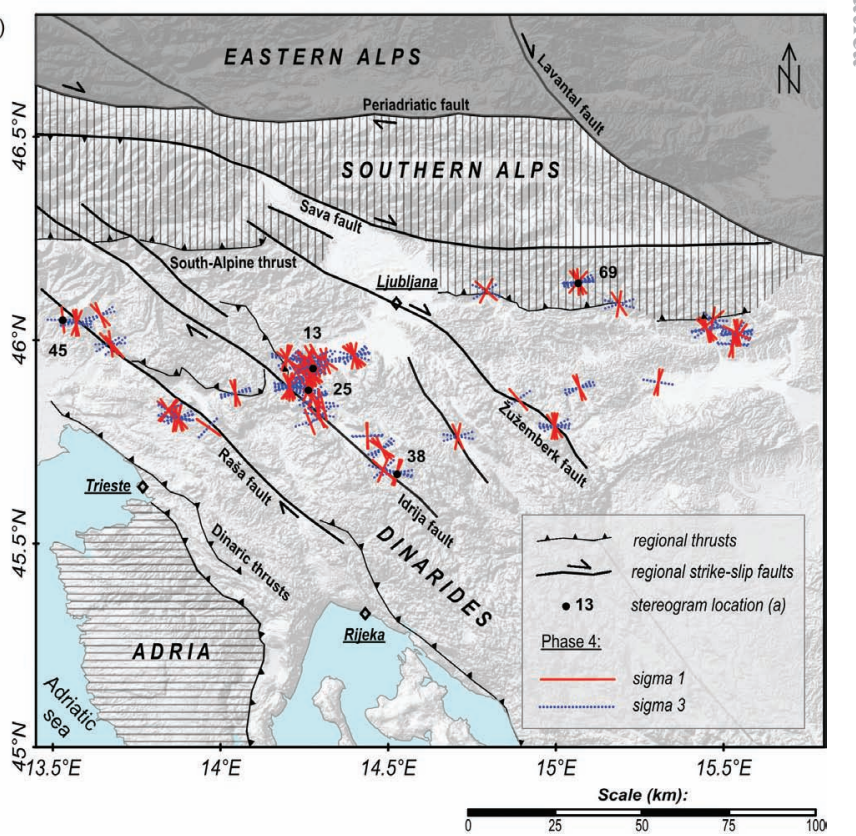

Figure 6. a) Examples of fault-slip data and derived stress tensors for Phase 4. b) Regional stress field of Phase 4 (in present-day reference frame, not accounting for any vertical-axis rotations).

\subsection{The overprinting relationship of different generations of fault striations on the same fault plane}

At Location 1 (Fig. 1) multiple generations of fault striations were documented on a single steep SW-dipping fault plane. On this plane slickenlines attributed to Phase 3 crosscut the dip-slip normal ones attributed to Phase 2 (Fig. 7 a). This structural relationship suggests that NE-SW oriented tension (Phase 2) is older than E-W oriented compression in the strike-slip palaeo-
Figure 7. Examples of slickenlines overprinting criteria described in the text documented at Location 1 as indicated in Fig. 1 (location 1; $x=90946$ $y=453387)$. a)
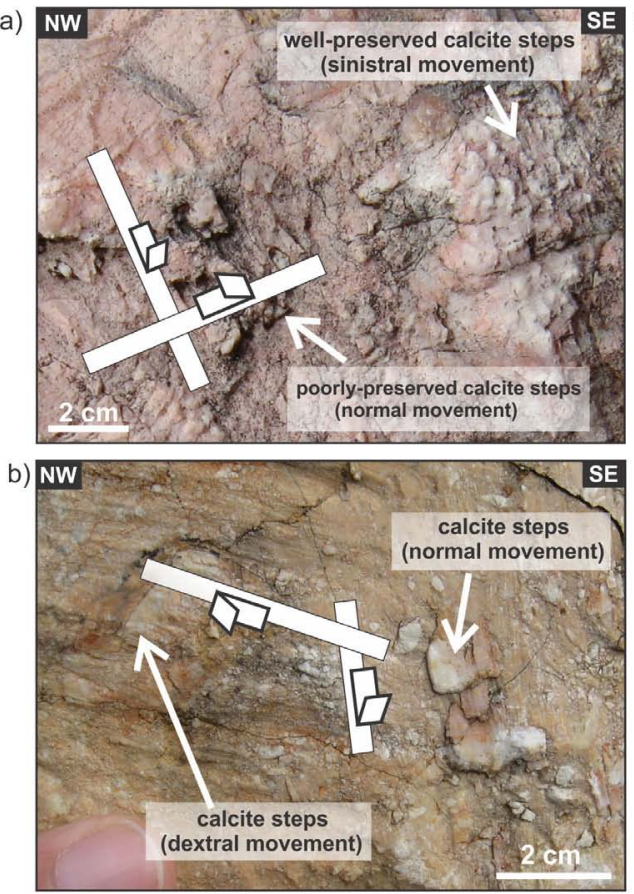

main direction of fault striation

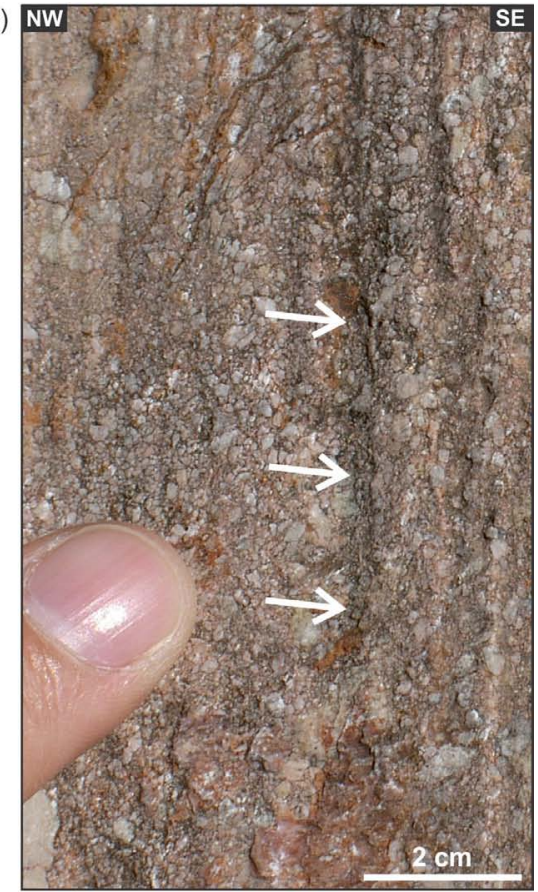

$\checkmark$ movement of the hanging wall 
stress regime (Phase 3). Besides, on the same fault plane, slickenlines that indicate dextral slip overprint the dip-slip normal ones (Fig. 7 b), which again clearly indicates that NE-SW oriented tension (Phase 2) predates strike-slip reactivation of this fault, this time however, in a NNW-SSE oriented compression in the strike-slip palaeostress regime attributed to Phase 4. Whereas the overprinting criteria of striae on fault planes are occasionally strongly influenced by the viewpoint of the observer and are therefore rarely unambiguous (SPERNER \& ZWEIGEL, 2010), the calcite accretionary steps that have grown inside sub-vertical grooves on this fault plane clearly indicate that the dextral sense of slip attributed to Phase 4 postdates the normal-slip episode of Phase 2 (Fig. 7 c).

\subsection{Cross-cutting relationships between a regional thrust plane and normal faults}

In central Slovenia the outcropping plane of the regional-scale Hrušica thrust (outcrop location P on Fig. 1 - in the central part of the Idrija fault zone south from the main fault trace, marked by red cross; also shown on Fig. 8) belonging to the Dinaric thrust system (PLACER, 1981) was examined. Here, the principal thrust plane, dipping $10^{\circ}$ towards the NNE to NE (Fig. $8 \mathrm{a}, \mathrm{c}$ ), is offset by small-scale NE-dipping normal faults, which exhibit dip-slip striae and calcite steps indicating normal slip (Fig 8 b, d). Again, this relationship suggests that the NE-SW tension (Phase 2) postdates Dinaric thrusting (Phase 1).
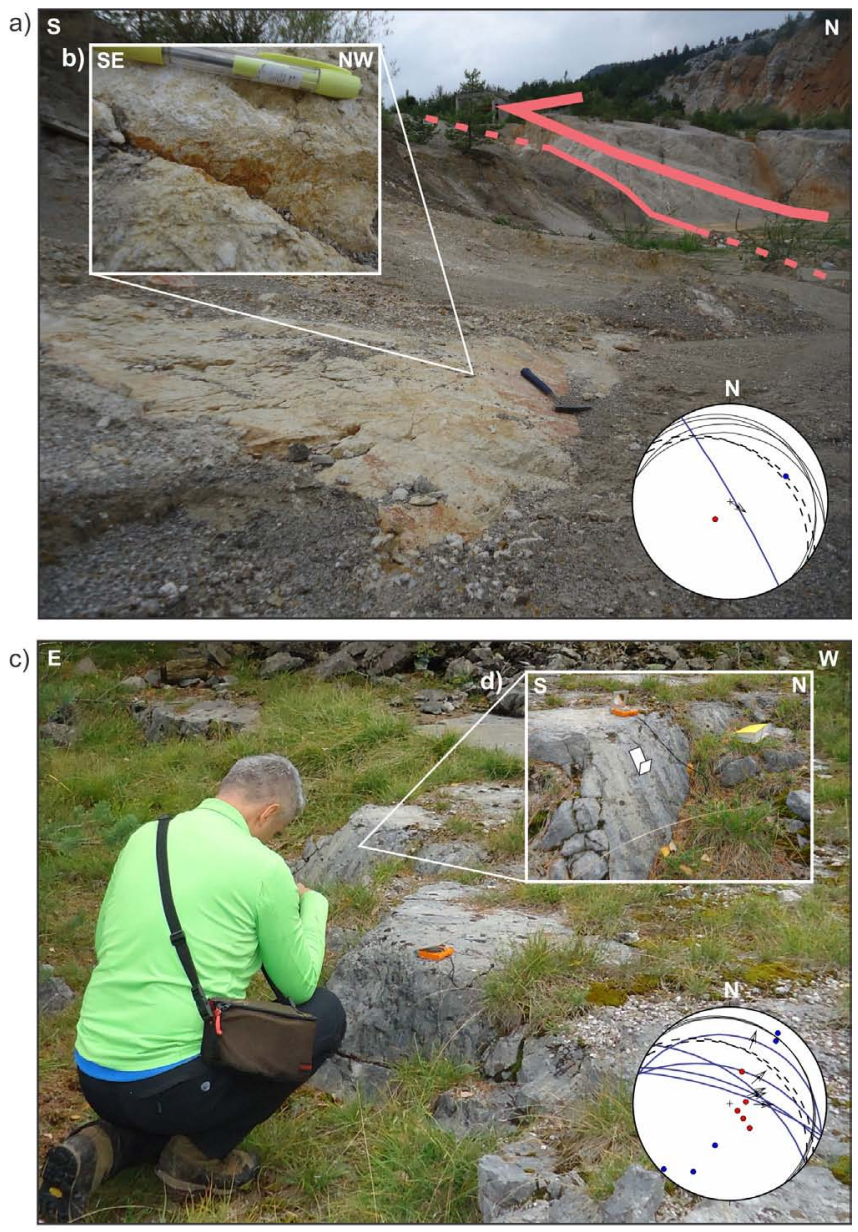

-. kinematic axis of normal faults $\uparrow$ normal faults _thrust - - bedding

Figure 8. Mesoscopic scale cross-cutting relationships where the thrust plane of the regional-scale Hrušica thrust is offset by small-scale normal faults (for outcrop location see Fig. $1 ; x=76192, y=441388$ ). See in text for details.

\section{The Ductile/brittle character of deformation}

The Bevk tectonic window mapped at location of $\mathrm{x}=95048$, $y=422800$ exposes highly-deformed Eocene flysch deposits below the Trnovo thrust (outcrop location 40 on Fig. 1, also shown on Fig. 9). This is the highest major thrust of the Dinaric thrust system of Slovenia (PLACER, 1981; MLAKAR \& ČAR, 2010). An approximately NE-SW-striking fault, which delimits the window to the east, rotated this structure so that here the Trnovo thrust plane dips slightly to the S(SW) instead of to the NE, which is typical elsewhere in the surrounding area. Eocene mudstones are strongly foliated (Fig. 9 a), with foliation intensity increasing towards the thrust contact. Micro folds and shear-bands in the foliation indicate top-to-the-S(SE) thrusting (Fig. 9 b). This foliation was cut under (semi)brittle conditions by WSWENE-striking shear zone with a clear sinistral sense of displacement, which produced decimetre-scale drag folds in the foliation and veins (Fig. 9 c). The shear zone was formed in NE-SW-oriented compression presumably during or immediately following the Dinaric thrusting, which we attributed to the palaeostress Phase 1. Moreover, this shear zone is cut by perpendicular dipslip-normal faults with $\mathrm{cm}$-scale displacements, which originated in NE-SW-directed tension attributed to Phase 2 (Fig. 9 d). Finally, brittle kinematic indicators on WSW-ENE-striking fault planes suggest late $\mathrm{N}(\mathrm{NNE})-\mathrm{S}(\mathrm{SSW})$ directed compression with perpendicular tension in the strike-slip regime attributed to Phase 4. Based on the described examples and criteria used for the relative chronology of the documented fault-slip datasets, we distinguished five groups of faults attributed to four palaeostress phases shown in Figure 10. The results of palaeostress calculations based on fault-slip data obtained in rocks of different ages are summarized in Figure 11.

\section{GEODYNAMIC INTERPRETATION}

The palaeostress Phase 1, which is characterized by NE-SW directed compression, is documented by slickenside lineation and indicators for the sense of slip that are scarcely and poorly preserved and documented in the study area. Moreover, the overprinting and cross-cutting relationships of faults attributed to this phase with younger faults indicate that Phase 1 is the oldest documented phase in the study area. As this phase was documented in Eocene flysch deposits, it is certainly of Eocene or post Eocene age. The same stress calculation was obtained from fault-slip data collected in Neogene rocks (Fig. 11), but only at four distinct locations with a wide span of calculated compression orientation. Since no mesoscale structures that could be related to NE-SW oriented compression were observed in Neogene rocks, these results are considered to be unreliable. Therefore, we constrained the age of palaeostress Phase 1 as Eocene or post-Eocene to preNeogene. In a regional tectonic framework it fits well with the Middle-Late Eocene thrusting of the External Dinarides towards the SW onto the undeformed Adria microplate (e.g. ILIĆ \& NEUBAUER, 2005; SCHMID et al., 2008; PLACER et al., 2010; VAN GELDER et al., 2015; Fig. 12).

Phase 2 is characterized by NE-SW oriented tension in the extensional tectonic regime (Fig. 12). Based on the relative chronology of slicken-side lineation and kinematic indicators, Phase 2 is older than Phases 3 and 4. With the assumption that Phase 1 is the oldest palaeostress phase of post-Eocene to pre-Neogene age, the activity of Phase 2 can be presumed to have occurred during the Neogene. Based on the presumed time of activity and calculated NE-SW directed tension perpendicular to the strike of the Dinaric orogen, Phase 2 correlates well with the Early and 
a)

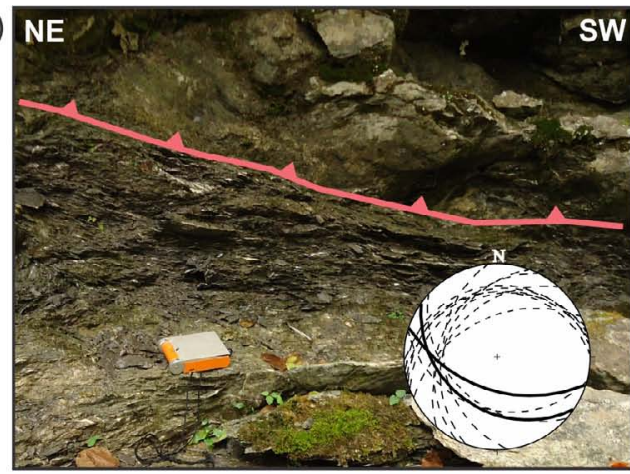

c)

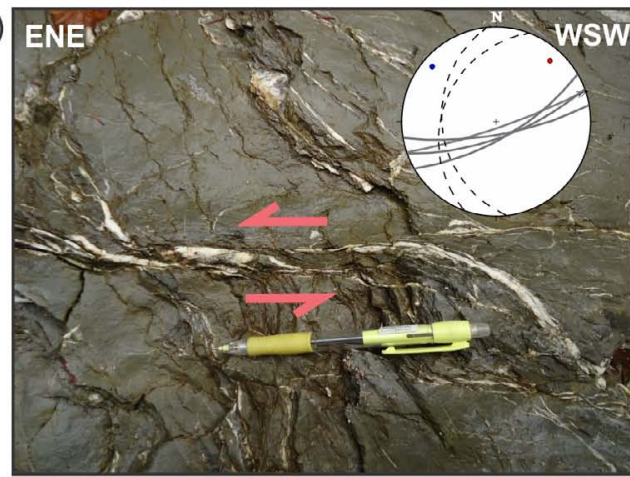

b)

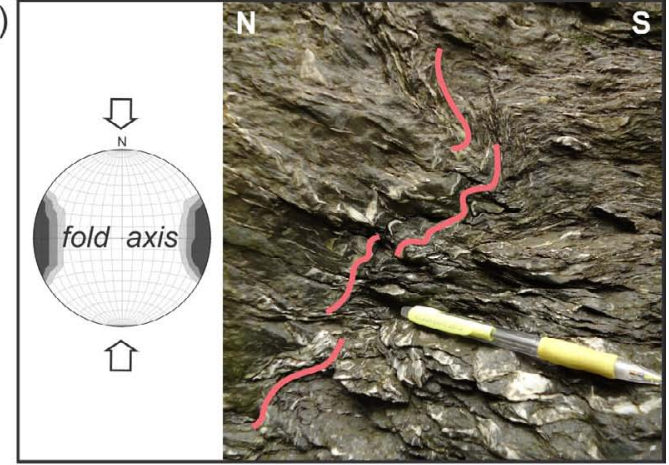

d) NW

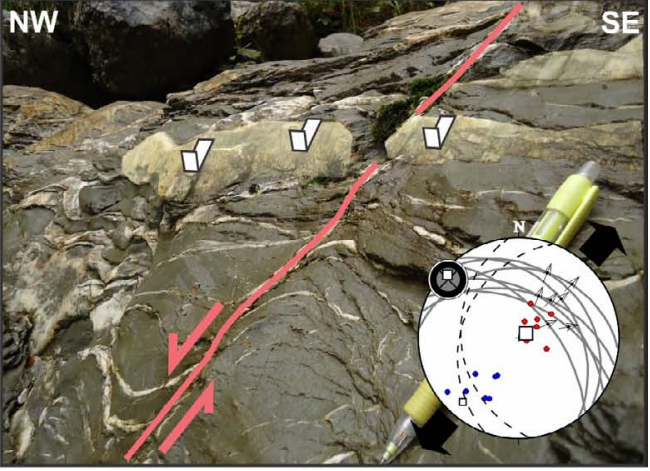

• kinematic axis for fault-slip data $\Rightarrow$ mean orientation $\sigma_{1} \Leftrightarrow \Rightarrow$ mean orientation $\sigma_{3} \quad \square \sigma_{1} \quad \square \sigma_{2} \quad \sigma_{3}$ $\sim$ micro folds strike-slip fault

$\square$ movement of the hanging wall

Figure 9. Ductile/brittle style of deformation (for location see Fig. 1). a) Foliated Eocene mudstone (dotted line on stereogram) below the thrust plane (continuous line on stereogram). b) Micro folds (indicated in red) in foliation. c) Drag folds in foliation and veins (dotted line on stereogram) along sinistral WSW-ENE-striking shear zone (continuous line on stereogram). d) The same shear zone cut by perpendicular dip-slip-normal faults (continuous line on stereogram).

\begin{tabular}{|c|c|c|c|}
\hline Paleostress phase & Fault-slip indicators & Outcrop-scale features & Map-scale features \\
\hline Phas & $\begin{array}{l}\text { Dip-slip striations on gently } \\
\text { inclined predominately SW- } \\
\text { dipping fault planes, but } \\
\text { mostly withoutdirect } \\
\text { kinematic indicators. }\end{array}$ & $\begin{array}{l}\text { Thrust planes associated } \\
\text { with strongly foliated } \\
\text { mudstones and cataclastically } \\
\text { deformend carbonates. } \\
\text { (Semi)ductile tear faults. } \\
\text { Duplex structures. }\end{array}$ & $\begin{array}{l}\text { Regional-scale NW-SE- } \\
\text { striking thrusts. }\end{array}$ \\
\hline $\mathrm{Ph}$ & $\begin{array}{c}\text { Dip-slip to oblique-slip } \\
\text { normal slickenlines, mainly } \\
\text { occurring on NW-SE-striking } \\
\text { fault planes. }\end{array}$ & $\begin{array}{c}\text { Meter-scale normal offsets on } \\
\text { NW-SE-striking fault planes } \\
\text { and m-scale conjugate } \\
\text { normal faults. }\end{array}$ & $\begin{array}{c}\text { Normal displacements and } \\
\text { block rotation along } \\
\text { NW-SE-striking faults. }\end{array}$ \\
\hline & $\begin{array}{l}\text { Predominately horizontal to } \\
\text { slightly oblique slickenlines } \\
\text { showing sinistral motion on } \\
\text { NW-SE-trending fault planes } \\
\text { and (less often) dextral slip } \\
\text { on NE-SW-trending fault } \\
\text { planes. }\end{array}$ & Not observed. & Not observed. \\
\hline Phase 4 & $\begin{array}{l}\text { Predominately horizontal to } \\
\text { slightly oblique slickenlines } \\
\text { showing dextral motion on } \\
\text { NW-SE-trending fault planes } \\
\text { and (less often) sinistral slip } \\
\text { on NE-SW-trending fault } \\
\text { planes. Dip-slip to oblique } \\
\text { reverse striations on gently } \\
\text { inclined approximately E-W- } \\
\text { striking fault planes. }\end{array}$ & $\begin{array}{l}\text { Centimeter-scale to m-scale } \\
\text { dextral offsets along NW-SE- } \\
\text { striking faults. }\end{array}$ & $\begin{array}{l}\text { Dextral offsets along } \\
\text { NW-SE-striking faults. }\end{array}$ \\
\hline
\end{tabular}

Figure 10. Relative chronology of documented palaeostress phases and description of related fault-slip datasets. 


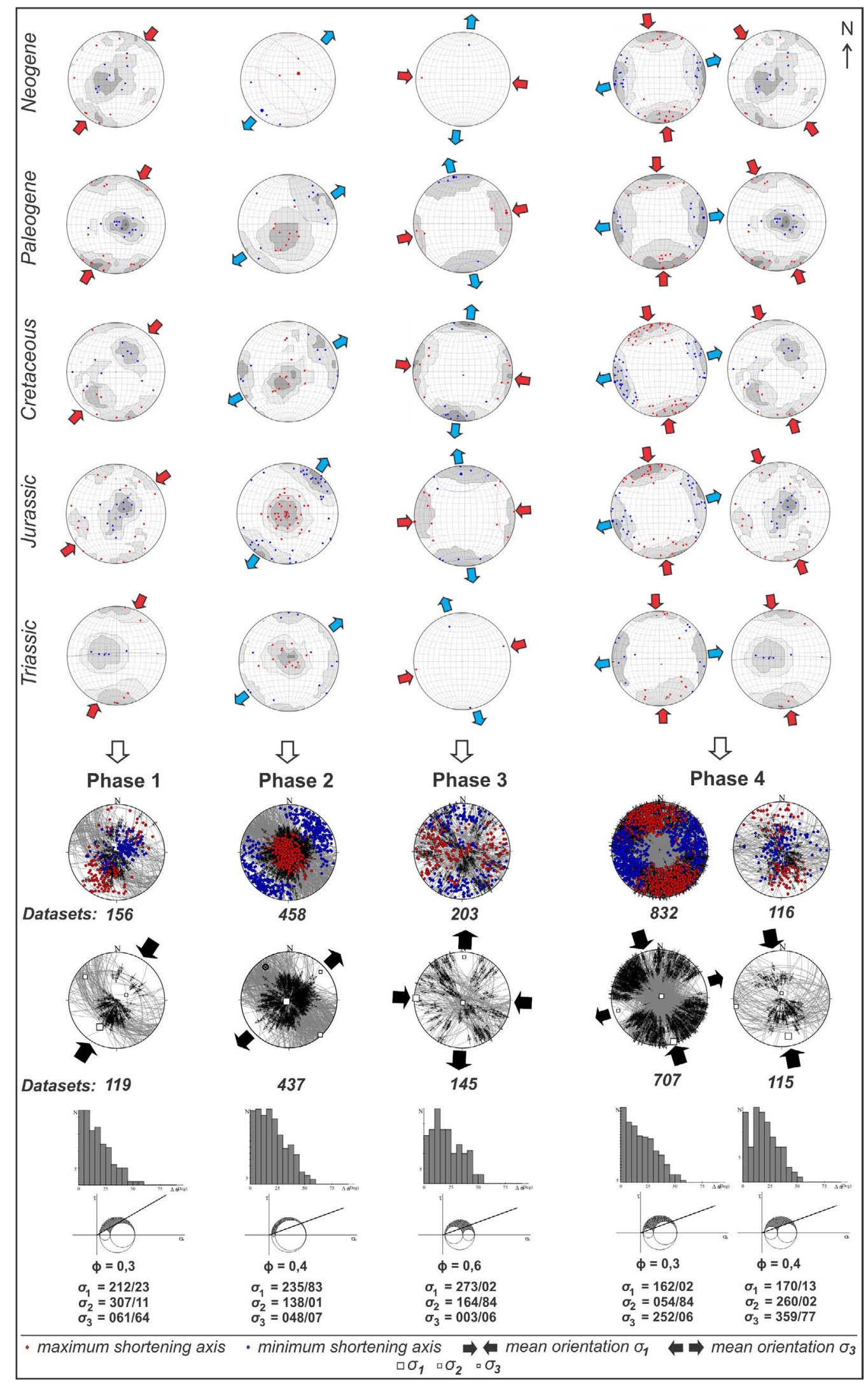

Figure 11. Comparison of determined palaeostress phases by age of rocks in which the fault-slip data was obtained. Each palaeostress tensor is represented by $\sigma_{1}$ orientation (red axis on stereograms) and $\sigma_{3}$ orientation (blue axis on stereograms). In the lower part of the Figure, mean palaeostress axis orientation and corresponding Mohr circle is shown for each phase.

Middle Miocene NE-SW oriented tension previously documented in the SW margin of the Pannonian basin (e.g. TOMLJENOVIĆ \& CSONTOS, 2001), in the Internal Dinarides (e.g. ILIĆ \& NEUBAUER, 2005) and in the Internal Dinarides - Pannonian basin transitional area (USTASZEWSKI et al., 2010). All the aforementioned studies assume that the Lower and Middle Miocene orogen perpendicular extensional phase is geodynamically related to the back arc extension in the Pannonian basin system. 


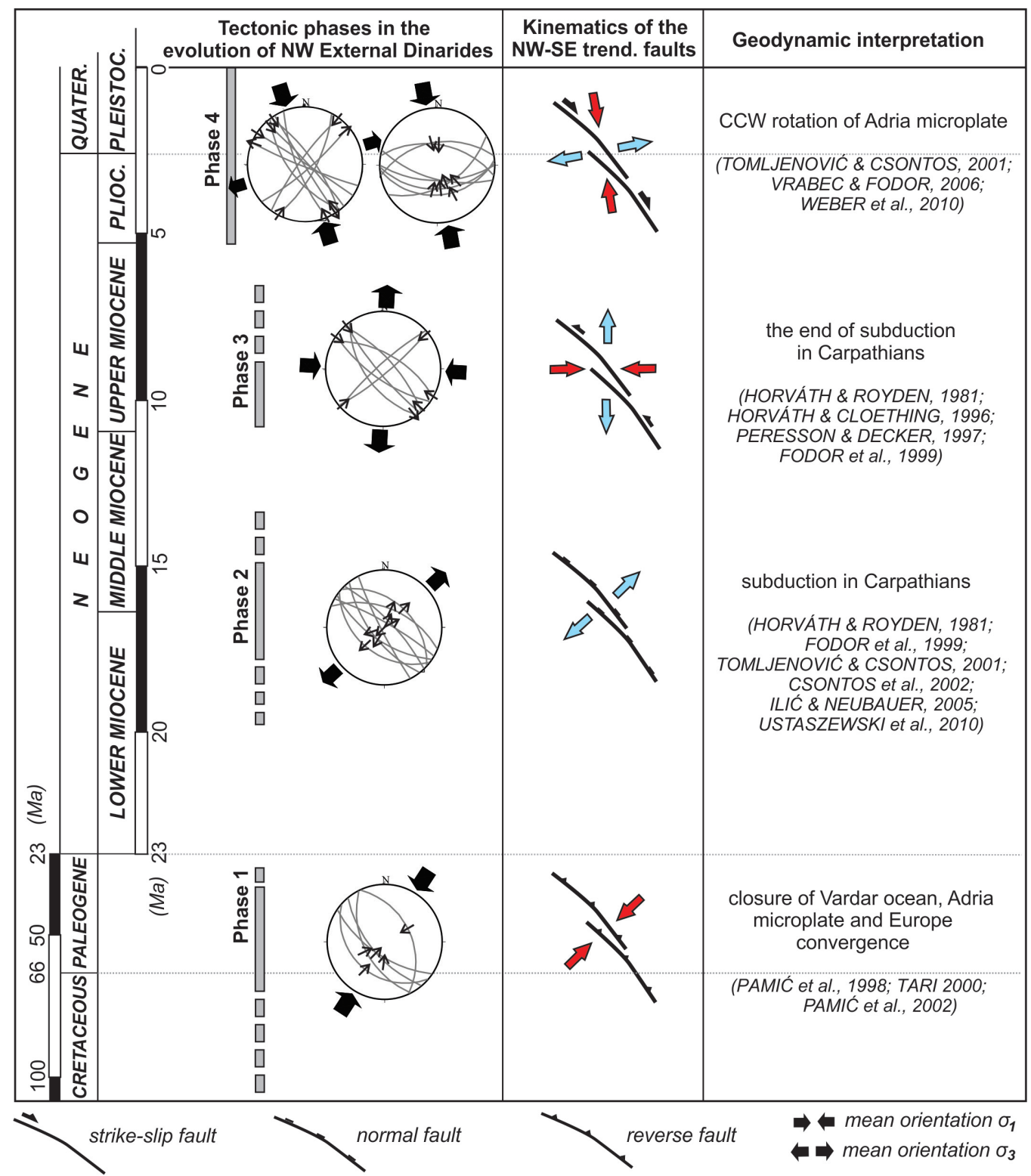

Figure 12. Geodynamic interpretation of the documented tectonic phases in the NW External Dinarides of Slovenia.

Phase 3 is marked by approximately E-W oriented compression with approximately N-S oriented tension in a strike-slip stress regime (Fig. 12). The relative chronology of slicken-side lineation and kinematic indicators show that Phase 3 is younger than Phase 2 and precedes Phase 4 which was presumably active since the Pliocene (see below). Therefore, the remaining time bracket for Phase 3 activity is the Late Miocene. In the DinaricAlpine-Carpathian-Pannonian region, the Late Miocene E-W oriented compression, which inverted previously sinistral NESW striking faults (formed during lateral extrusion in Early and Middle Miocene) into Late Miocene reverse faults was first described in the Vienna basin by PERESSON \& DECKER (1997). Later, corresponding faults were detected in different parts of the Pannonian basin system (e.g. FODOR et al., 1999). According to PERESSON \& DECKER (1997) this Late Miocene change of palaeostress reflects the cessation of subduction in the Eastern Carpathians which in turn disabled further eastward extrusion in the Eastern Alps. Therefore, the final pulse of subduction in the Eastern Carpathians may have established an E-W directed compressive regional stress field, that could have been transmitted through the crust of the Pannonian basin into the
Eastern Alps (PERESSON \& DECKER, 1997), and possibly even further south-westwards into the NW External Dinarides, thus causing inversion of the steep NW-SE striking normal faults in the NW External Dinarides into faults with a sinistral sense of slip (Fig. 12).

Palaeostress tensors attributed to Phase 4 that is characterized by approximately N-S oriented compression and approximately E-W oriented tension in a strike-slip stress regime is the most ubiquitous phase in the study area, coinciding with the recent stress tensors of the wider South Alpine-Dinarides transitional area (e.g. CAPORALI et al., 2013). Thus, it is probably representative of the well known inversive/transpressive regional phase in the NW External Dinarides and the SW margin of the Pannonian basin (e.g. TOMLJENOVIĆ \& CSONTOS, 2001; USTASZEWSKI et al., 2010; Fig. 12). In this area, NW-SE striking steep to subvertical dextral faults are known as active during the Pliocene and Quaternary time (e.g. KASTELIC et al., 2008; HERAK et al., 2009; MOULIN et al., 2014), and their origin is explained by CCW rotation of the Adria microplate (TOMLJENOVIĆ \& CSONTOS, 2001; MÁRTON et al., 2002; VRABEC \& FODOR, 2006; WEBER et al., 2010). 


\section{CONCLUSIONS}

According to the results of palaeostress analysis it was possible to separate (at least) four different stress tensor groups that have affected the NW External Dinarides in Slovenia from the Late Eocene to the Recent.

During the Neogene, the majority of the stress was accumulated and released along generally NW-SE striking faults (and to those fault related structures). The current study demonstrates that these faults have a complex polyphase kinematic history.

The oldest palaeostress tensor group (Phase 1) is characterized by NE-SW directed compression, manifested by reverse slips along generally NW-SE striking faults. Regionally this phase can be correlated with the main Eocene top-to-the-SW thrusting phase of the External Dinarides. The second palaeostress tensor group (Phase 2) is marked by NE-SW directed tension. This phase normally inverted older reverse and thrust faults connected to Dinaric thrusting (Phase 1). Normal inversion of NW-SE striking earlier reverse faults is obviously an important tectonic phase, evident not only in outcrop but also in map-scale structures. Regionally this phase coincides with back arc, syn-rift extension in the Pannonian basin system. The time bracket for this phase is Lower to Middle Miocene. The third palaeostress tensor group (Phase 3) is characterised by approximately E-W oriented compression with approximately N-S oriented tension in the strike-slip stress regime. Generally, E-W directed compression probably induced sinistral inversion of earlier NW-SE striking normal faults. Regionally this phase can be correlated with the Late Miocene short pulse of E-W directed compression, documented in the Vienna basin and also in different parts of the Pannonian basin system. The youngest palaeostress tensor group (Phase 4) is characterized by approximately N-S oriented compression and perpendicular approximately E-W oriented tension in the strike-slip stress regime, but also by generally N-S oriented compression in a pure compressional stress regime. This phase is partly accommodated by generally E-W striking reverse faults that overprinted older structures and partly by dextral inversion of previously formed faults with Dinaric strike. Regionally, this phase correlates well with the recent inversive/transpressive tectonic phase in the wider South Alpine - NW Dinarides area.

\section{ACKNOWLEDGEMENT}

This research was funded by the Slovenian Research Agency (Young researcher grant-contract number 1000-09-310070 and program group P1-0195 Geochemical and structural processes). Authors are grateful to Asta GREGORIČ for fault-slip data from her Diploma thesis. We would like to thank to Bruno TOMLJENOVIĆ for editorial handling and his careful review that significantly improved the manuscript. We would also like to thank to another anonymous reviewer for many constructive comments.

\section{REFERENCES}

ANGELIER, J. (1994): Fault slip analysis and palaeostress reconstruction.- In: HANCOCK, P.L. (eds.): Continental deformation. Pergamon Press, Oxford, 53-99.

BABIĆ, L., HERNITZ KUČENJAK, M., ĆORIĆ, S. \& ZUPANIČ J. (2007): The Middle Eocene age of the supposed Late Oligocene sediments in the flysch of the Pazin basin (Istria, Outer Dinarides).- Natura Croatica, 16, 83-103.

BARTOL, M., MIKUŽ, V. \& HORVAT, A. (2014): Palaeontological evidence of communication between the Central Paratethys and the Mediterranean in the late Badenian/early Serravalian.- Palaeogeogr. Palaeocl., 394, 144-157. doi: 10.1016/j. palaeo.2013.12.009

BAVEC, M., CAR, M., STOPAR, R., JAMŠEK RUPNIK, P. \& GOSAR, A. (2012): Geophysical evidence of recent activity of the Idrija fault, Kanomlja, NW Slovenia.- Materials and geoenvironment, 59, 247-256.
BISHOP, A.W. (1966): The strength of soils as engineering materials.- Geotechnique, 16, 91-130.

BOTT, M.H.P. (1959): The mechanisms of oblique slip faulting.- Geol. Mag., 96, $109-117$.

BUDKOVIČ, T., ŠAJN, R. \& GOSAR, M. (2003): Environmental impact of active and abandoned mines and metal smelters in Slovenia.-Geologija, 46/1, 135-140. doi: 10.5474/geologija.2003.014

BUSER, S., FERJANČIČ, L., GRAD, D., KERČMAR-TURNŠEK, D., MENCEJ, S., OREHEK, S., PAVLOVEC, R., PLENIČAR., M., PRESTOR, L., RIJAVEC, L. \& ŠRIBAR, L. (1963): Osnovna geološka karta SFRJ 1 : 100 000, List Postojna.Sav. Geol. Zavod, Beograd.

BUSETTI, M., VOLPI, V., NICOLICH, R., BARISON, E., ROMEO, R., BARADELLO, L., BRANCATELLI, G., GIUSTINIANI, M., MARCHI, M., ZANOLLA, C., WARDELL, N., NIETO, D. \& RAMELLA, R. (2010): Dinaric tectonic features in the Gulf of Trieste (northern Adriatic Sea).- B. Geofis. Teor. Appl., 51/2-3, $117-128$.

CAPORALI, A., NEUBAUER, F., OSTINI, L., STANGL, G. \& ZULIANI, D. (2013): Modeling surface GPS velocities in the Southern and Eastern Alps by finite dislocations at crustal depths.- Tectonophysics, 590, 136-150. doi: 10.1016/j.tecto.2013.01.016

CASTELlARIN, A., CANTELli, L., FESCE, A.M., MERCIER, J.L., PICOTTI, V., PINI, G.A., PROSSER, G. \& SELLI, L. (1992): Alpine compressional tectonics in the Southern Alps. Relationships with the N-Apennines.- Annales tectonicae, 4, 62-94.

ČRNE, A.E. \& GORIČAN, S̆. (2008): The Dinaric carbonate platform margin in the early Jurassic: a comparison between succession in Slovenia and Montenegro.Boll. Soc. Geol. Ital., 127/2, 389-405.

DEBELJAK, I., KOŠIR, A., BUFFETAUT, E. \& OTONIČAR, B. (2002): The Late Cteraceous dinosaurs and crocodiles of Kozina (SW Slovenia): a preliminary study.- Memorie - Società Geologica Italiana, 57, 193-201.

DOBLAS, M. (1998): Slickenside kinematic indicators.- Tectonophysics, 295, 187-197.

DOGLIONI, C. \& BOSELLINI, A. (1987): Eoalpine and mesoalpine tectonics in the Southern Alps.- Int. J. Earth Sci., 76, 735-754.

DROBNE, K., ĆOSOVIĆ, V., MORO, A. \& BUCKOVIĆ, D. (2011): The Role of the Paleogene Adriatic Carbonate Platform in the Spatial Distribution of Alveolinids.Turk. J. Earth Sci., 20, 721-751. doi: 10.3906/yer-0911-76

FODOR, L., JELEN, B., MÁRTON, E., SKABERNE, D., ČAR, J. \& VRABEC, M. (1998): Miocene-Pliocene tectonic evolution of the Slovenian Periadriatic fault: Implications for Alpine-Carpathian extrusion models.- Tectonics, 17, 690-709.

FODOR, L., CSONTOS, L., BADA, G., GYÖRFI, I. \& BENKOVICS, L. (1999): Tertiary tectonic evolution of the Pannonian basin system and neighbouring orogens: a new synthesis of palaeostress data.- In: DURAND, B., JOLIVET, L., HORVÁTH, F. \& SÉRANNE, M. (eds.): The Mediterranean Basins: Tertiary extension within the Alpine Orogen. Geological Society, London, Special Publications, 156, 295-334.

FODOR, L., JELEN, B., MÁRTON, E., RIFELJ, H., KRALJIĆ, M., KEVRIĆ, R., MARTON, P., KOROKNAI, B. \& BALDI-BEKE, M. (2002): Miocene to Quaternary deformation, stratigraphy and paleogeography in Northeastern Slovenia and Southwestern Hungary.- Geologija, 45, 103-114. doi:10.5474/geologija.2002.009

VAN GELDER, I., MATENCO, L., WILLINGSHOFER, E., TOMLJENOVIĆ, B., ANDRIESSEN, P.A.M., DUCEA, M.N., BENIEST, A. \& GRUIĆ, A. (2015): The tectonic evolution of a critical segment of the Dinarides-Alps connection: Kinematic and geochronological inferences from the Medvednica Mountains, NE Croatia.- Tectonics, 34, 1952-1978. doi: 10.1002/2015TC003937

GOSAR, A. (1998): Seismic reflection surveys of the Krško basin structure: implications for earthquake hazard at the Krško nuclear power plant, southeast Slovenia.- J. Appl. Geophys., 39, 131-153.

GREGORIČ, A. (2005): Analiza razvoja paleonapetosti v Dinarskem narivnem sistemu zahodne Slovenije (okolica Nove Gorice).- Unpubl. Diploma Thesis, Faculty of Natural Sciences and Engineering, University of Ljubljana, 84 p.

HANDY, R.M., USTASZEWSKI, K. \& KISSLING, E. (2015): Reconstructing the AlpsCarpathians-Dinarides as a key to understanding switches in subduction polarity, slab gaps and surface motion.- Int. J. Earth Sci., 104, 1-26. doi: 10.1007/s00531014-1060-3

HERAK, D., HERAK., M. \& TOMLJENOVIĆ, B. (2009): Seismicity and earthquake focal mechanisms in North-Western Croatia.- Tectonophysics, 465, 121-220. doi: 10.1016/j.tecto.2008.12.005

HORVÁTH, F. \& ROYDEN, L. (1981): Mechanism for the Formation of the Intra-Carpathian Basins: a Review.- Earth Evolution Science, 3, 307-316.

HORVÁTH, F. \& CLOETINGH, S. (1996): Stress-induced late-stage subsidence anomalies in the Pannonian Basin.- Tectonophysics, 266, 287-300.

ILIĆ, A. \& NEUBAUER, F. (2005): Tertiary to recent oblique convergence and wrenching of the Central Dinarides: Constraints from palaeostress study.- Tectonophysics, 410, 465-484. doi: 10.1016/j.tecto.2005.02.019

JAMŠEK RUPNIK, P., BENEDETTI, L., PREUSSER, F., BAVEC, M. \& VRABEC, M. (2014): Geomorphic evidence of recent activity along the Vodice thrust fault 
in the Ljubljana Basin (Slovenia) a preliminary study.- Ann. Geophys. Italy, 56, 1-8. doi: 10.4401/ag-6252

JELEN, B. \& RIFELJ, H. (2002): Stratigraphic structure of the B1 Tertiary tectonostratigraphic unit in eastern Slovenia.- Geologija, 45/1, 115-138.

JEŽ, J., OTONIČAR, B., FUČEK, L. \& OGORELEC, B. (2011): Late Cretaceous sedimentary evolution of a northern sector of the Adriatic Carbonate Platform (Matarsko Podolje, SW Slovenia).- Facies, 57/3, 447-468. doi: 10.1007/s10347-0100249-6

KASTELIC, V., VRABEC, M., CUNNINGHAM, D. \& GOSAR, A. (2008): Neo-Alpine structural evolution and present-day tectonic activity of the eastern Southern Alps: The case of the Ravne Fault, NW Slovenia.- J. Struct. Geol., 30, 963-975. doi: 10.1016/j.jsg.2008.03.009

KASTELIC, V. \& CARAFA, M. (2012): Fault slip rates for active Exterlam Dinarides thrust-and-fold belt.- Tectonics, 31, 1-18. doi: 10.1029/2011TC003022

KASTELIC, V., VANNOLI, P., BURRATO, P., FRACASSI, U., TIBERTI, M.M. \& VALENSISE, G. (2013): Seismogenic sources in the Adriatic Domain.- Mar. Petrol. Geol., 42, 191-213. doi: 10.1016/j.marpetgeo.2012.08.002

MÁRTON, E., FODOR, L., JELEN, B., MÁRTON, P., RIFELJ, H. \& KEVRIĆ, R. (2002): Miocene to Quaternary deformation in NE Slovenia: complex paleomagnetic and structural study.- J. Geodyn., 34, 627-651

MIKUŽ, V., BARTOL, M. \& ULAGA, Š. (2012): The brachiopod Lingula from the Middle Miocene - Badenian beds of Slovenia.- Geologija, 55/2, 271-274. doi: 10.5474/geologija.2012.017

MLADENOVIĆ, A., TRIVIĆ, B. \& CVETKOVIĆ, V. (2015): How tectonics controlled post-collisional magmatism within the Dinarides: Inferences based on study of tectono-magmatic events in the Kopaonik Mts. (Southern Serbia).- Tectonophysics, 646, 36-49. doi: 10.1016/j.tecto.2015.02.001

MLAKAR, I. \& ČAR, J. (2010): Geological map of the Idrija - Cerkljansko hills between Stropnik and Rovte 1 : 25.000.- Geological Survey of Slovenia, Ljubljana.

MOULIN, A., BENEDETTI, L., GOSAR, A., JAMŠEK RUPNIK, P., RIZZA, M., BOURLÈS, D. \& RITZ, J.F. (2014): Determining the present-day kinematics of the Idrija fault (Slovenia) from airborne LiDAR topography.- Tectonophysics, 628, 188-205. doi: 10.1016/j.tecto.2014.04.043

NOZAEM, R., MOHAJJEL, M., ROSSETTI, F., DELLA SETA, M., VIGNAROLI, G., YASSAGHI, A., SALVINI, F. \& ELIASSI, M. (2013): Post-Neogene right-lateral strike-slip tectonics at the north-western edge of the Lut Block (Kuh-e-Sarhangi Fault), Central Iran.- Tectonophysics, 589, 220-233. doi: 10.1016/j.tecto.2013.01.001

OTONIČAR, B. (2007): Upper Cretaceous to Paleogene forbulge unconformity associated with foreland basin evolution (Kras, Matarsko Podolje and Istria; SW Slovenia and NW Croatia).- Acta Carsol., 36, 101-120.

PAMIĆ, J., GUŠIĆ, I. \& JELASKA, V. (1998): Geodynamic evolution of the Central Dinarides.- Tectonophysics, 297, 251-268. doi: 10.1016/S0040-1951(98)00171-1

PAMIĆ, J., TOMLJENOVIĆ, B. \& BALEN, D. (2002): Geodynamic and petrogenetic evolution of Alpine ophiolites from the central and NW Dinarides: an overview.Lithos, 65, 113-142. doi: 10.1016/S0024-4937(02)00162-7

PAVLOVEC, R. (2012): Numulitine iz Zunanjih Dinaridov.- Folia biologica et geologica, 53/3, 85-109.

PERESSON, H. \& DECKER, K. (1997): Far-field effects of Late Miocene subduction in the Eastern Carpathians: E-W compression and inversion of structures in the Alpine-Carpathian-Pannonian region.- Tectonics, 16/1, 38-56.

PETIT, J.P. (1987): Criteria for the sense of movement on fault surfaces in brittle rocks.J. Struct. Geol., 9, 597-608.

PICHA, F.J. (2002): Late Orogenic Strike-Slip Faulting and Escape Tectonics in Frontal Dinarides-Hellenides, Croatia, Yugoslavia, Albania, and Greece.- AAPG Bull., 86/9, 1659-1671.

PLACER, L. (1981): Geologic structure of Southwestern Slovenia.- Geologija, 24, 27-60.

PLACER, L. (1982): Structural history of the Idrija mercury deposit.- Geologija, 25, $7-94$.

PLACER, L. \& ČAR, J. (1997): Structure of Mt. Blegoš between the Inner and Outer Dinarides.- Geologija, 40, 305-323. doi: 10.5474/geologija.1997.016

PLACER, L. (1998): Contribution to macrotectonic subdivision of the border region between Southern Alps and External Dinarides.- Geologija, 41, 223-255. doi: 10.5474/geologija.1998.013

PLACER, L., ŽIVČIĆ, M. \& VRABEC, M. (2001): Recent deformation and seismic activity at the Adria microplate boundary in Western Slovenia and Croatia.- In: BADA, G. (eds.): Quantitative neotectonics and seismic hazard assessment: new integrated approaches for environmental management. Malév Air Tours, 74-75.

PLACER, L. (2008): Principles of the tectonic subdivision of Slovenia.- Geologija, 51, 205-217. doi: 10.5474/geologija.2008.021
PLACER, L., VRABEC, M. \& CELARC, B. (2010): The bases for understanding of the NW Dinarides and Istria Peninsula tectonics.- Geologija, 53, 55-86. doi: 10.5474/ geologija.2010.005

POLJAK, M., ŽIVČIĆ, M. \& ZUPANČIČ, P. (2000): The Seismotectonic Characteristics of Slovenia.- Pure Appl. Geophys., 157, 37-55.

SCHMID, S.M., FÜGENSCHUH, B., KISSLING, E. \& SCHUSTER, R. (2004): Tectonic map and overall architecture of the Alpine orogen - Eclogae Geol. Helv., 97, 93-117. doi: 10.1007/s00015-004-1113-x

SCHMID, S.M., BERNOULLI, D., FÜGENSCHUH, B., MATENCO, L., SCHEFER, S., SCHUSTER, R., TISCHLER, M. \& USTASZEWSKI, K. (2008): The AlpineCarpathian-Dinaridic orogenic system: correlation and evolution of tectonic units.Swiss J. Geosci., 101, 139-183. doi: 10.1007/s00015-008-1247-3

SPERNER, B. \& ZWEIGEL, P. (2010): A plea for more caution in fault-slip analysis.Tectonophysics, 482/1-4, 29-41. doi: 10.1016/j.tecto.2009.07.019

TARI, V. (2002): Evolution of the northern and western Dinarides: a tectonostratigraphic approach.- In: BERTOTTI, G., SCHULMANN, K. \& CLOETINGHH, S.A.P.L. (eds.): Continental collision and the tectono - sedimentary evolution of the forelands. EGU Stephan Mueller Special Publication Series, 1, 223-236.

TOMLJENOVIĆ, B. \& CSONTOS, L. (2001): Neogene-Quaternary structures in the border zone between Alps, Dinarides and Pannonian Basin (Hrvatsko zagorje and Karlovac Basins, Croatia).- Int. J. Earth Sci., 90, 560-578. doi: 10.1007/ s005310000176

TOMLJENOVIĆ, B., CSONTOS, L., MÁRTON, E. \& MÁRTON, P. (2008): Tectonic evolution of the northwestern Internal Dinarides as constrained by structures and rotation of Medvednica Mountains, North Croatia.- In: SIEGESMUND, S., FÜGENSCHUH, B. \& FROITZHEIM, N. (eds.): Tectonic Aspects of the AlpineDinaride-Carpathian System. Geological Society, London, Special Publications, 298, 145-167. doi: 10.1144/SP298.8

TURNŠEK, D., BUSER, S. \& RAMOVŠ, A. (1982): Triassic reefs in Slovenia.-Facies, $6,15-24$.

USTASZEWSKI, K., SCHMID, S.M., FÜGENSCHUH, B., TISCHLER, M., KISSLING, E. \& SPAKMAN, W. (2008): A map-view restoration of the AlpineCarpathian-Dinaridic system for the Early Miocene.- Swiss J. Geosci., 101/1, 273-294. doi: 10.1007/s00015-008-1288-7

USTASZEWSKI, K., KOUNOV, A., SCHMID, S.M., SCHALTEGGER, U., KRENN, E., FRANK, W. \& FÜGESCHUH, B. (2010): Evolution of the Adria-Europe plate boundary in the northern Dinarides: From continent-continent collision to backarc extension.- Tectonics, 29, 1-34. doi:10.1029/2010TC002668

VRABEC, M. \& FODOR, L. (2006): Late Cenozoic Tectonics of Slovenia: Structural Styles at the Northeastern Corner of the Adriatic Microplate-- In: PINTER, N., GRENERCZY, G., WEBER, J., STEIN, S. \& MEDAK, D. (eds.): The Adria Microplate: GPS Geodesy, Tectonics and Hazards. NATO Science Series, IV, Earth and Environmental Sciences, 61, 151-168.

WALLACE, R.E. (1951): Geometry of shearing stress and relation to faulting.- J. Geol., $59,118-130$

WEBER, J., VRABEC, M., STOPAR, B., PAVLOVIČ-PREŠEREN, P. \& DIXON, T. (2006): The PIVO-2003 experiment: A GPS study of Istria Peninsula and Adria microplate motion, and active tectonics in Slovenia.- In: PINTER, N., GRENERCZY, G., WEBER, J., STEIN, S. \& MEDAK, D. (eds.): The Adria Microplate: GPS Geodesy, Tectonics and Hazards. NATO Science Series, IV, Earth and Environmental Sciences, 61, 305-320.

WEBER, J., VRABEC, M., PAVLOVIČ-PREŠEREN, P., DIXON, T., JIANG, Y. \& STOPAR, B. (2010): GPS-derived motion of the Adriatic microplate from Istria Peninsula and Po Plain sites, and geodynamic implications.- Tectonophysics, 483, 214-222. doi: 10.1016/j.tecto.2009.09.001

ZAJC, M., CELARC, B. \& GOSAR, A. (2015): Structural-geological and karst feature investigations of the limestone-flysch thrust-fault contact using low-frequency ground penetrating radar (Adria-Dinarides thrust zone, SW Slovenia).- Environmental earth sciences, 73, 8237-8249. doi: 10.1007/s12665-014-3987-x

ŽALOHAR, J. \& VRABEC, M. (2007): Paleostress analysis of heterogeneous fault-slip data: The Gauss method.- J. Struct. Geol., 29, 1798-1810. doi: 10.1016/j. jsg.2007.06.009

ŽALOHAR, J. \& VRABEC, M. (2008): Combined kinematic and paleostress analysis of fault-slip data: The Multiple-slip method.- J. Struct. Geol., 30, 1603-1613. doi: 10.1016/j.jsg.2008.09.004

ŽIBRET, L. \& ŽIBRET, G. (2014): Use of geomorphological indicators for the detection of active faults in southern part of Ljubljana moor, Slovenia.- Acta Geogr. Slov., 54, 271-291. doi: 10.3986/AGS54203

ŽIBRET, L. (2015): Kinematic and paleostress evolution of the NW-SE trending Dinaric faults in the northwestern External Dinarides.- Unpubl. PhD Thesis, Faculty of Natural Sciences and Engineering, University of Ljubljana, 84 p. 